demic Press, New York, pp 424-525

10. Zlotkin SH, Bryan MH, Anderson GH 1981 Intravenous nitrogen and energy intakes required to duplicate in utero nitrogen accretion in prematurely born infants. J Pediatr 99:115-120

11. Widdowson EM 1981 Changes in body composition during growth. In: Davies J, Dobbing J (eds) Scientific Foundations of Paediatrics, 2nd ed. Heinemann, London, pp 330-342

12. Zlotkin SH 1984 Intravenous nitrogen intake requirements in full-term newborns undergoing surgery. Pediatrics 73:493-496
13. Pencharz P, Beesley J, Canagarayar U, Van Aerde J, Renner J, Sauer P, Wesson D, Swyer P 1984 Protein metabolism of parenterally fed neonates: combined $13 \mathrm{C}$ and $15 \mathrm{~N}$ studies. Pediatr Res 18:A672

14. O'Keefe SJD, Moldawer LL, Young VR, Blackburn GL 1981 The influence of intravenous nutrition on protein dynamics following surgery. Metabolism 30:1150-1154

15. Pencharz PB, Masson M, Desgranges F, Papageorgiou A 1984 The effects of post-natal age of the whole body protein metabolism and urinary 3-methylhistidine excretion of premature infants. Nutr Res 4:9-19

\title{
Announcement
}

\section{Announcement of the 1986 Pediatric Endocrinology Examination}

The Subspecialty Committee of Pediatric Endocrinology of the American Board of Pediatrics will administer its next certifying examination on Friday, July 18, 1986.

The following criteria must be met to be eligible to sit for the examination: 1) certification by the American Board of Pediatrics; 2) 2 years of full-time graduate training in pediatric endocrinology; 3) verification of training and recommendation by Pediatric Endocrinology Program Director.

Each application will be considered individually and must be acceptable to the Subspecialty Committee of Pediatric Endocrinology.

Registration for this examination will extend from October 1, 1985, until January 31, 1986. To request an application, please contact the Board office at the address listed below.

The application fee for the written examination is $\$ 635$ ( $\$ 235$ processing and evaluating $+\$ 400$ examination). Candidates who are not approved to take the examination will be refunded the examination fee. The processing and evaluating fee will be retained.

Please direct any inquiries to: American Board of Pediatrics, 111 Silver Cedar Court, Chapel Hill, NC 27514-1651 (919) 9290461 . 